\title{
The first step towards energy revolution
}

\section{Santanu Bandyopadhyay ${ }^{1}$}

Published online: 5 February 2019

c) Springer-Verlag GmbH Germany, part of Springer Nature 2019
Prof. Bruno Burger of Fraunhofer Institute for Solar Energy Systems revealed that power generation from the renewable energy sources (218.9 TWh) overtook coal-based power generation (207 TWh) in 2018 in Germany (Burger 2019). This is a significant step towards achieving sustainable power generation for the future. In most countries, renewables have emerged as the fastest growing energy source. Solar and wind are undergoing very rapid growth. Among others, bioenergy, geothermal, and hydropower are also growing steadily. The impact of this extraordinary growth in renewables has mostly been felt in the electricity sector, and Germany is an excellent example of it. Today, renewables account for about $25 \%$ of global electricity generation. In a recent report, International Renewable Energy Agency has identified six factors behind significant growth of the renewable energy sector (IRENA 2019): declining cost of renewables, factors affecting climate change, technological improvements in the energy sector, governmental declarations to achieve certain renewable targets, voluntary pledges of various corporations, and changing perceptions of the public.

In some special cases, such as remote locations or islands, renewable power is cost-effective. In recent years, with strong governmental support, the levelized cost of some renewable technologies are comparable to the conventional fossil fuel-based power generation cost, through the capital investment is still significant. Increase in energy conversion efficiency of solar photovoltaic modules, increasing the height of wind turbines, applications of data analytics to develop smart power generation, etc., started playing a significant role in growth and adaptation of renewable power. For the developed economy, the capital investment in the renewable sector with appropriate policy and subsidy may pay off over a long time horizon and even helps in economic growth. Considering the social cost of environmental

Santanu Bandyopadhyay

santanub@iitb.ac.in

1 Department of Energy Science and Engineering, Indian Institute of Technology Bombay, Powai, Mumbai 400076, India pollution and climate change, the effective cost of renewable power is significantly low. Still, it may not be possible for low- and middle-income economies to invest high capital in the renewable sector, especially diverting funds from direct socially relevant schemes. On the other hand, unreliability and restricted availability of electric power in many lowincome economics have prepared users to use the 'power as available', as opposed to the 'power on demand' mentalities of the high economics. This may enable them to implement locally available renewable solutions at a much lower cost, considering the variability of renewables. Energy efficiency, which enables economic growth with lower energy inputs, is also an attractive alternative for these countries. Big data and machine learning can improve energy efficiency significantly without significant capital investment. In the last century, the average growth rate of global GDP was approximately $3 \%$, and the growth for energy demand was also the same. In recent decades, the direct relationship between the two has been broken due to improvements in energy efficiency. In the coming few decades, the primary energy demand is expected to grow annually at $1 \%$ for the world, while the expected growth of global GDP is forecasted to be $3.4 \%$ per year (IEA 2018). Energy efficiency may not directly influence the use of renewables; it may create the pathways for cost-effective renewable substitutions by reducing the overall demand.

The future energy system is shaping up on the basis of three important factors: improvements in energy efficiency, the growth of renewables, and the applications of data analytics. Data analytics can make the energy system smart and can fuel improving energy efficiency as well as the use of locally available renewables. At this point, it should be noted that the energy efficiency is not just the reduction in fuel, and similarly, the renewable energy is just not a simple fuel substitution. They are much beyond these. Improved energy efficiency reduces energy requirement without sacrificing energy services, and thus, reduces production cost with improved market competitiveness. If planned and implemented properly, locally collected and locally utilized renewables can significantly improve the local economy. Unlike fossil fuels, which are available in some selected 
pockets, renewables are distributed all over the world. They have a prominent influence on local as well as the global landscape of the world in terms of social, political, as well as economic significances. Energy system transitions of coal to oil for the transportation sector and coal to natural gas for the electricity sector have changed the geopolitical equations between haves and have-nots. But renewables, with its locally available nature, can completely revolutionize the energy politics of the world. It will not be an exaggeration to claim that we have already taken the first step towards the energy revolution.

\section{References}

Burger B (2019) Öffentliche Nettostromerzeugung in Deutschland im Jahr 2018. www.energy-charts.de/downloads/Stromerzeu gung_2018_1.pdf. Accessed 25 Jan 2019

IEA (2018) World Energy Outlook 2018. International Energy Agency IRENA (2019) A new world: the geopolitics of the energy transformation. International Renewable Energy Agency, Abu Dhabi

Publisher's Note Springer Nature remains neutral with regard to jurisdictional claims in published maps and institutional affiliations. 